\title{
Effects of Climate and Land-Use Change on the Establishment and Growth of Cembran Pine (Pinus cembra L.) over the Altitudinal Treeline Ecotone in the Central Swiss Alps
}

Author(s): Pascal Vittoz, Benoît Rulence, Thierry Largey, and François Freléchoux

Source: Arctic, Antarctic, and Alpine Research, 40(1):225-232.

Published By: Institute of Arctic and Alpine Research (INSTAAR), University of Colorado

DOI: http://dx.doi.org/10.1657/1523-0430(06-010)[VITTOZ]2.0.CO;2

URL: http://www.bioone.org/doi/full/10.1657/1523-0430\%2806-010\%29\%5BVITTOZ\%5D2.0.CO\%3B2

BioOne (www.bioone.org) is a nonprofit, online aggregation of core research in the biological, ecological, and environmental sciences. BioOne provides a sustainable online platform for over 170 journals and books published by nonprofit societies, associations, museums, institutions, and presses.

Your use of this PDF, the BioOne Web site, and all posted and associated content indicates your acceptance of BioOne's Terms of Use, available at www.bioone.org/page/terms_of_use.

Usage of BioOne content is strictly limited to personal, educational, and non-commercial use. Commercial inquiries or rights and permissions requests should be directed to the individual publisher as copyright holder. 


\section{Effects of Climate and Land-Use Change on the Establishment and Growth of Cembran Pine (Pinus cembra L.) over the Altitudinal Treeline Ecotone in the Central Swiss Alps}

\author{
Pascal Vittoz $* \dagger \S$ \\ Benoit Rulence† \\ Thierry Largey† and \\ François Freléchoux : \\ *Faculty of Geosciences and \\ Environmental Sciences, University of \\ Lausanne, Bâtiment Biophore, 1015 \\ Lausanne, Switzerland \\ $\dagger$ Department of Ecology and Evolution \\ (Faculty of Biology and Medicine), \\ University of Lausanne, Bâtiment \\ Biophore, 1015 Lausanne, Switzerland \\ \#WSL Antenne romande, Swiss Federal \\ Research Institute, Case postale 96, 1015 \\ Lausanne, Switzerland \\ $\S$ Corresponding author: \\ pascal.vittoz@unil.ch
}

\begin{abstract}
Tree growth is generally limited by temperature in cold climates and by water availability in arid zones. Establishment in altitudinal treeline ecotones depends on the temperature, but may be very sensitive to water availability as well. We studied the effect of climate and land use on the colonization and growth of Pinus cembra in the treeline ecotone of the dry Central Swiss Alps; one site was influenced by timber harvest and cattle activity and another one was undisturbed. Stands were sampled at three elevations: in the forest and the lower and upper parts of the treeline ecotone. The age structure was similar in all sites, ranging from uneven-aged (forest) to more even-aged, with recent densification and upslope expansion of the treeline ecotone. However, recruitment started at the treeline around 1850 (the end of the Little Ice Age) in the undisturbed site, simultaneously with an increase of tree-ring growth, but about 60 years later at the other site, after cattle grazing decreased. These results, and the positive correlation of radial growth with summer and previous autumn temperatures indicated that, in this altitudinal treeline ecotone, growth and establishment are mainly linked to temperature. However, drought stress was visible in the lowest stands, with a positive correlation of growth with rainfall during the previous autumn and December, and in August of the growing season. This could limit growth in a future warmer climate.
\end{abstract}

\section{Introduction}

Since the 19th century, an altitudinal and latitudinal expansion of trees has been observed in many altitudinal or boreal treeline ecotones (e.g. Brink, 1959; Kullman, 1986; Taylor, 1995; Shiyatov, 2003; Camarero and Gutiérrez, 2004). This is generally attributed to the warmer conditions which followed the end of the Little Ice Age. However, such forest expansion was not observed everywhere, and tree recruitment is sometimes mainly a densification of the altitudinal treeline ecotone (Szeicz and MacDonald, 1995; Camarero and Gutiérrez, 1999; Mazepa, 2005). The low dispersal capacity of the species explains locally the absence of expansion (Mazepa, 2005), but microclimate conditions are often important. Shrubs, krummholz, or adult trees keep a higher soil moisture, protect against wind abrasion, and modify snow distribution, all conditions which may improve (nurse effects) seedling survival in the first years and favor establishment (e.g., Szeicz and MacDonald, 1995; Camarero and Gutiérrez, 1999; Holtmeier and Broll, 2005). Moreover, infrequent disturbances, like avalanches, fire, extreme snow cover, or drought, may kill newly established seedlings or trees above the treeline ecotone and maintain a long-term stable position of the treeline (Noble, 1993).

Simultaneously with treeline expansion, a radial growth increase was observed in alpine and boreal treeline ecotones (e.g., Briffa et al., 1995; Motta and Nola, 2001; Paulsen et al., 2000). This growth trend already started in 19th century (Rolland et al., 1998) and was locally particularly visible in the last decades (Szeicz and MacDonald, 1995; Paulsen et al., 2000; Lloyd and Fastie, 2002). This increase is generally attributed to higher temperatures, as summer temperatures are generally the main limiting factor for radial growth (Tranquillini, 1979; Schweingruber, 1985; Körner and Paulsen, 2004). However, radial growth in treeline ecotones of dry regions may be limited by summer drought (e.g., Sierra Nevada, U.S.A., Lloyd and Graumlich, 1997; Argentina, Daniels and Veblen, 2004), and increasing evapotranspiration coupled to increasing temperature instigated a growth decrease in treeline ecotone trees in Alaska (Lloyd and Fastie, 2002). In the Alps, rainfall is generally abundant in the treeline ecotone and water is less limiting for growth than in other ranges (Tranquillini, 1979). However, Petitcolas (1998) found that a drought during the previous summer influenced the growth of four conifer species in the French Alps and, in Austria, winter drought was found to be a limiting factor for the growth of Pinus cembra L. (Oberhuber, 2004).

Tree recruitment and growth in treeline ecotones are thus strongly dependent on climatic conditions, but both factors were not influenced in the same manner. Few studies directly compared both parameters, but Daniels and Veblen (2004) showed that climatic conditions which facilitated Nothofagus pumilio (Poepp et Endl.) Krasser establishment and radial growth varied through time and were often opposite. Conversely, Camarero and Gutiérrez (1999) found that warm springs and wet summers enhanced both recruitment and radial growth of Pinus uncinata DC. in the Spanish Pyrenees.

These previous examples show that warmer temperatures may have very distinct consequences on treeline ecotones. An increase in radial growth may depend on sufficient water availability to compensate for the increased evapotranspiration, and an upslope 
expansion needs good seed dispersal, germination, seedling establishment, and survival during several decades above the treeline. These factors may be linked to moisture availability, snow cover, and infrequent disturbances. It is thus necessary to consider all these aspects to predict the consequences of future climate change on treeline ecotone vegetation.

In the European Alps, the influence of climate change on the treeline ecotone is confounded by human activities. Anthropogenic fires, timber harvesting, and cattle activity lowered the treeline ecotone since $\sim 4800 \mathrm{BP}$ in Switzerland (Tinner and Theurillat, 2003). However, cattle activity has been decreasing in subalpine and alpine pastures since the start of the Industrial Revolution (around 1850), and trees are recolonizing previously open areas (Bätzing, 1991). It is thus often not possible to separate the relative influence of climate warming after the Little Ice Age and decreasing human activities on the observed upslope tree expansion (Stützer, 1999; Motta and Nola, 2001).

The Central Swiss Alps, surrounded by numerous 4000-mhigh summits, is the driest part of the Alps (Walter and Lieth, 1967). The climate is sub-continental, with high daily and seasonal temperature ranges, frequent clear skies, and low humidity. This climate is responsible for one of the highest treeline ecotones in the Alps (Brockmann-Jerosch, 1919). One rare, undisturbed treeline in Switzerland is located in the study region, which gave us the opportunity to compare recent changes in tree recruitment and radial growth in the treeline ecotone in relation to the disturbed vs. undisturbed conditions and to the dry, subalpine environment. We hypothesized that: (1) the treeline ecotone expanded upslope and density increased since the end of the Little Ice Age, independently of direct anthropogenic impact; (2) radial growth increased simultaneously, and likewise during the warming observed during the last decades; and (3) precipitation is a driving factor for Pinus cembra tree-ring growth in this dry region.

\section{Material and Methods}

\section{STUDY SITES}

We selected two linear transects $9 \mathrm{~km}$ apart through the altitudinal treeline ecotone in the Central Swiss Alps (Fig. 1). The treeline ecotone was defined as the level situated between the end of the closed forest and the last upright tree (height $>2 \mathrm{~m}$ and diameter at breast height $(\mathrm{DBH})>7 \mathrm{~cm})$. Forests are dominated by Pinus cembra and Larix decidua Miller, with an undergrowth of Rhododendron ferrugineum L. and Vaccinium myrtillus L. The first transect lies above the village of Grächen $\left(46^{\circ} 11^{\prime} \mathrm{N}, 7^{\circ} 51^{\prime} \mathrm{E}\right)$, between 2200 and $2580 \mathrm{~m}$ a.s.1., on a large rock field. Because the surface is very irregular, it is unlikely that any significant timber harvest or cattle grazing has taken place in recent centuries and therefore the position of the treeline ecotone is most likely natural. $P$. cembra is the only species at the top end of the transect. The second transect lies above Ginals $\left(46^{\circ} 15^{\prime} \mathrm{N}, 7^{\circ} 47^{\prime} \mathrm{E}\right)$, between 2100 and $2350 \mathrm{~m}$ a.s.l. This site is mostly on deep soils and the site has been exploited for a long time, with timber harvesting and summer cattle grazing, as in most of the Alps (Bätzing, 1991). P. cembra and L. decidua both occur along the whole transect. Both sites are on siliceous bedrock, with a western to northwestern aspect and a similar slope (ca. $30^{\circ}$ ).

\section{CLIMATE}

Temperature and precipitation data from 1901 to 2000 were collected at the MeteoSwiss station at Grächen (1620 m a.s.1.). Missing monthly values (62 between 1900 and 1932) were estimated (Fritts, 1976) using linear regressions from the years

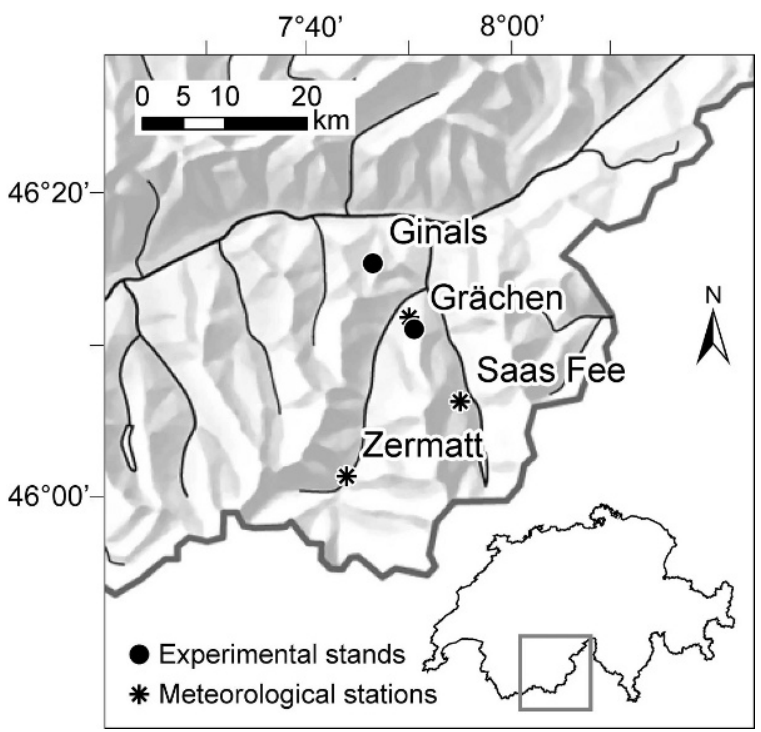

FIGURE 1. Location of the study sites and related meteorological stations in Switzerland.

where there were also data from Saas Fee $(1785 \mathrm{~m}, 12 \mathrm{~km}$ from Grächen) for temperature and Zermatt $(1610 \mathrm{~m}, 20 \mathrm{~km}$ from Grächen; Fig. 1) for precipitation.

In Grächen, the average annual precipitation $( \pm 1$ SD) for 1901-2000 was $577 \pm 116 \mathrm{~mm}$, with the winters drier (mean of the sum for December to February $112 \pm 57 \mathrm{~mm}$ ) than the summers (June to August $160 \pm 46 \mathrm{~mm}$ ). The data were very variable, with the total annual precipitation ranging between 297 and $881 \mathrm{~mm}$ and total monthly values between 1 and $256 \mathrm{~mm}$. The coefficient of variation ranged from 83 to $85 \%$ in winter months and 45 to $53 \%$ in summer months.

The mean annual temperature was $4.7 \pm 0.8^{\circ} \mathrm{C}\left(-3.5 \pm 2.1^{\circ} \mathrm{C}\right.$ in January and $13.8 \pm 1.6^{\circ} \mathrm{C}$ in July). During the 20th century, the mean annual temperature increased from 4.29 to $5.24^{\circ} \mathrm{C}$ (linear regression significant, $p=0.0001$ ). This increase took place mainly during two periods (1900-1921 and 1980-2000), separated by a more or less stable mean temperature between 1921 and 1980 . Warming was especially marked at the end of the century, with an increase of $1.9^{\circ} \mathrm{C}$ in winter in the period from 1966 to 2000 (linear regression, $p=0.0075$ ) and of $2.4^{\circ} \mathrm{C}$ in summer (Fig. $2 ; p<0.0001$ ).

\section{CORE SAMPLING AND MEASUREMENTS}

At each site, three stands were selected along the transect at different altitudes: in the forest (just under the treeline ecotone), in the lower part of the treeline ecotone, and among the last trees in upper part of the treeline ecotone (Table 1). Only trees with $2 \mathrm{~m}$ in height and DBH $>7 \mathrm{~cm}$ were considered. In the forest and lower treeline stands, 20 Pinus cembra trees were randomly selected along horizontal lines (closest tree every $20 \mathrm{~m}$ ). In the upper treeline stands, we chose all the trees growing at the end of the transect (only 14 were available in Ginals). Trees were measured for height and DBH. In September 2000, two cores were taken, one upslope and the second perpendicularly at breast height in the forest and lower treeline stands at $50 \mathrm{~cm}$ above the root collar for upper treeline stands. The characteristics of the stands and trees are summarized in Table 1.

The cores were mounted and sanded, and tree-ring widths were measured with an accuracy of within $0.01 \mathrm{~mm}$. We followed standard visual cross-dating procedures with the help of the software XMATCH98 (Fowler, 1998) and evaluated the results 


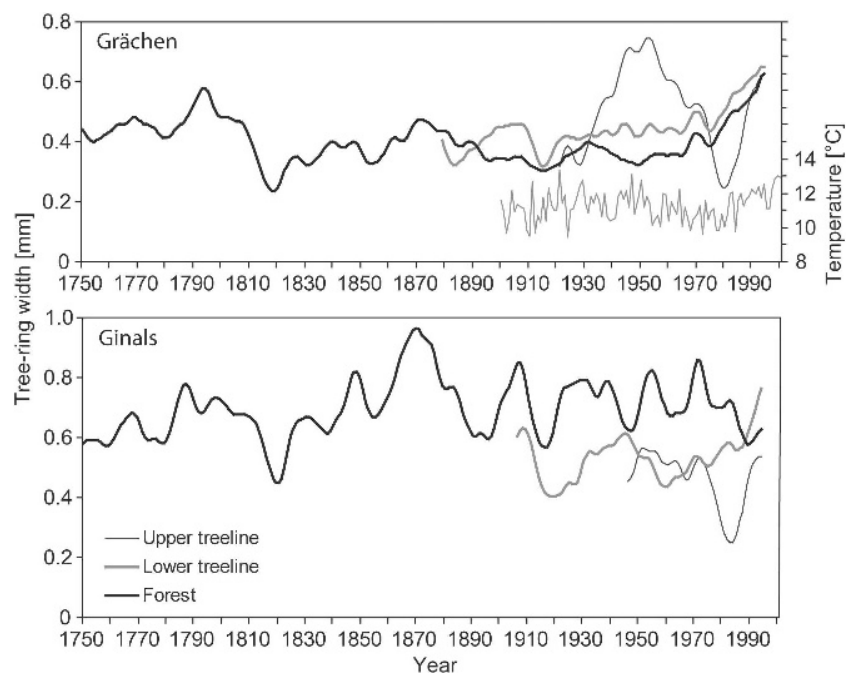

FIGURE 2. Tree-ring width (age-detrended) in Grächen and Ginals and average growth season temperature in Grächen (Central Swiss Alps, $1620 \mathrm{~m}$ a.s.l.). The tree-ring curves are smoothed means of tree-ring widths after removing age effects (Paulsen et al., 2000), and the growth season temperature is the average of monthly values from May to September.

with COFECHA (Holmes, 1983) in ITRDBLIB (Grissino-Mayer et al., 1997). Cross-dating showed that missing or false rings were rare (Table 1). Trees were aged by counting rings, and missing rings to the pith were estimated when necessary using Duncan's (1989) method. Tree age is underestimated when coring above the stem base. According to Motta and Nola (2001), Pinus cembra needs about 20 years to grow to $50 \mathrm{~cm}$ in height at $2200 \mathrm{~m}$ a.s.l.

\section{ANAL YSES}

Two detrending procedures were used. The first one (Paulsen et al., 2000) aimed to compare absolute tree-ring growth through time and between stands. The effect of age on growth was first removed, as the age structure of the stands differed. For this, the cores which included the pith or were close to it were selected to calculate the age effect curve following Paulsen et al. (2000). The 83 selected series were aligned according to cambial age, and a cubic polynomial function was fitted to the first 150 years, as tree rings older than 150 years did not show any age effect: $\mathrm{f}($ age $)=3 *$ $10^{-7} *$ age $^{3}-2 * 10^{-4} 0.0002 *$ age $^{2}+0.0167 *$ age +0.6194 . The series were individually detrended with this function between 20 and 150 years and multiplied by the average width of tree rings older than 150 years $(0.46 \mathrm{~mm})$. The whole correction was: ringwidth $^{\prime}=0.46 *$ ringwidth $* \mathrm{f}(\text { age })^{-1}$. Tree rings between 0 and 20 years old were not used as they showed more irregular values. The other trees, whose cores were not reliable for age estimation, were not detrended, and only the flat part of the series was used. The annual mean ring growth of the stands was calculated by aligning the series (one core per tree) with the correct calendar year, and annual growth was averaged for every stand and smoothed with a 13-year reciprocal low-pass filter (Fritts, 1976) in order to remove high-frequency signals. Only years with four or more series were considered.

The second detrending procedure used a classical dendrochronological method (Fritts, 1976) to produce a standardized chronology for each stand and to compare tree-ring growth with climate. As many young trees did not cover the complete 20th century, we selected the longest and best cross-dated series for this period and standardized them by fitting a negative exponential curve $(33.8 \%$ of series), a straight line with a negative slope (13.8\%), or, if both of these failed, a horizontal line (52.5\%) which equals the mean ring-width value and so does not remove any growth trends. We used the software ARSTAN (Cook, 1985) for the standardization, which simultaneously calculates descriptive statistics of the chronology (Table 1) and a residual chronology where autocorrelation is removed to enhance the climate signal. The residual chronologies were compared with the mean monthly temperature and total monthly precipitation from August of the previous year to September of the growth year. Bootstrapped

TABLE 1

Elevation and tree characteristics (mean \pm 1 SD) for the sampled stands (A) and statistics for the tree-ring width residual chronologies (B). The proportion of corrected rings is the percentage of missing or false rings in the cores; the mean sensitivity is the relative change in ring-width from year to year; the mean correlation between cores is a coefficient calculated from the pairwise comparison of all series in the chronology; the variance explained in first eigenvector is the percentage of common variance among ring-width series explained by the first principal component (Fritts, 1976); the signal-to-noise ratio and expressed population signal are both measures of chronology confidence (Wigley et al., 1984).

\begin{tabular}{|c|c|c|c|c|c|c|c|}
\hline & \multirow[b]{2}{*}{ Stands } & \multicolumn{3}{|c|}{ Grächen } & \multicolumn{3}{|c|}{ Ginals } \\
\hline & & Forest & Lower treeline & Upper treeline & Forest & Lower treeline & Upper treeline \\
\hline \multirow[t]{8}{*}{$\mathbf{A}$} & Elevation and tree characteristics & & & & & & \\
\hline & Elevation $(\mathrm{m})$ & 2200 & 2320 & $2500-2580$ & 2120 & 2230 & $2300-2350$ \\
\hline & Height (m) & $13.0 \pm 4.3$ & $8.2 \pm 3.8$ & $4.4 \pm 1.6$ & $13.3 \pm 6.8$ & $7.6 \pm 2.6$ & $3.5 \pm 1.5$ \\
\hline & Diameter (cm) & $37.8 \pm 16.6$ & $28.3 \pm 10.6$ & $23.6 \pm 11.2$ & $36.4 \pm 22.4$ & $23.1 \pm 16.7$ & $16.4 \pm 6.7$ \\
\hline & Tree age (years) & $289 \pm 216$ & $129 \pm 68$ & $89 \pm 37$ & $307 \pm 296$ & $104 \pm 97$ & $62 \pm 40$ \\
\hline & Ring width (mm) & $0.63 \pm 0.45$ & $1.02 \pm 0.60$ & $1.13 \pm 0.66$ & $0.77 \pm 0.49$ & $1.04 \pm 0.57$ & $1.01 \pm 0.64$ \\
\hline & Prop. of trees cored to the pith $(\%)$ & 10 & 30 & 30 & 10 & 35 & 28.6 \\
\hline & Prop. of corrected rings $(\%)$ & 0.21 & 0.12 & 0.43 & 0.31 & 0.09 & 0.51 \\
\hline \multirow[t]{8}{*}{ B } & Residual chronology & & & & & & \\
\hline & Number of series in chronology (trees) & $14(11)$ & $15(9)$ & $15(11)$ & $12(8)$ & $12(10)$ & $9(7)$ \\
\hline & Full chronology span & $1900-2000$ & 1914-2000 & $1948-2000$ & $1900-2000$ & $1941-2000$ & $1955-2000$ \\
\hline & Mean sensitivity & 0.13 & 0.14 & 0.16 & 0.14 & 0.15 & 0.19 \\
\hline & Mean correlation between cores & 0.25 & 0.31 & 0.32 & 0.39 & 0.34 & 0.20 \\
\hline & Variance in first eigenvector $(\%)$ & 30.1 & 37.4 & 37.6 & 44.7 & 39.7 & 29.5 \\
\hline & Signal-to-noise ratio & 4.55 & 5.95 & 7.19 & 6.93 & 6.16 & 1.91 \\
\hline & Expressed population signal & 0.82 & 0.86 & 0.88 & 0.87 & 0.86 & 0.66 \\
\hline
\end{tabular}


Grächen
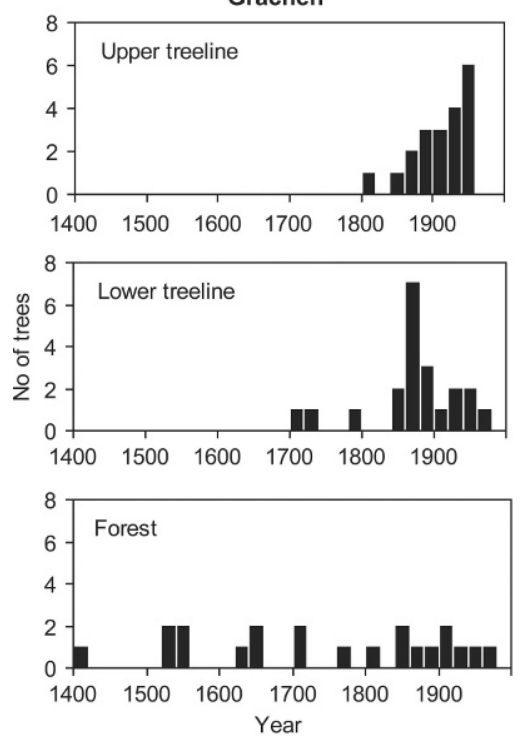

Ginals
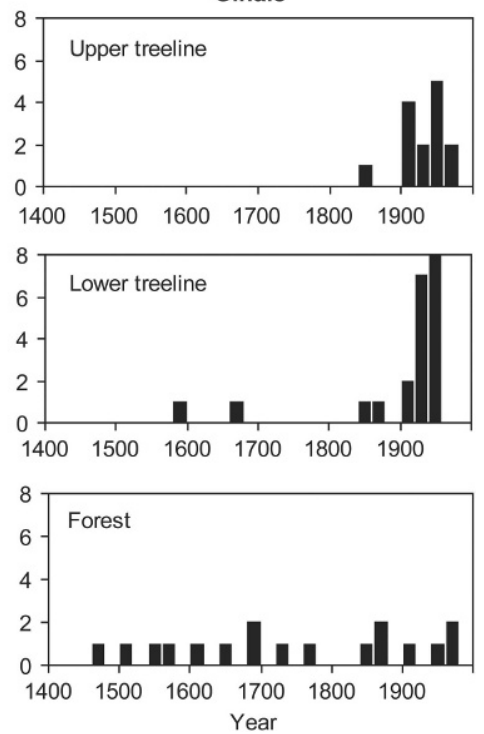

FIGURE 3. Tree age structure of six stands in the Central Swiss Alps: number of new trees per 20year classes. Grächen stands were undisturbed and Ginals stands were influenced by timber harvest and cattle grazing. response function analyses (Fritts, 1976; Briffa and Cook, 1990) were performed with PRECON software (Fritts, 1999) using the principal components, linearly independent of climatic data, with 1000 replications and without previous years, as autocorrelation had already been removed from the chronologies.

\section{Results}

\section{AGE STRUCTURE}

At each transect level, the age structure was similar in both transects, but with temporal differences (Fig. 3). In the forests, we found old trees with a regular regeneration over centuries; at the lower treeline ecotones, the majority of trees were young, with a few old trees, and at the upper treeline we found only young trees (established after 1800). However, the two transects differed with respect to the age of the most recent colonization. It began at the lower and upper treeline stands mainly around 1840 in Grächen, and about 60 years later in Ginals. Numerous saplings and seedlings at the treeline indicated that the colonization is ongoing, and the last visible age class in Figure 3 certainly did not correspond to the end of the colonization. As all the trees in upper treeline stands were cored, tree limit expanded upslope after 1800 in both transects.

\section{GROWTH TREND}

The growth curves had similar patterns at both sites (Fig. 2). Both forest stands showed a growth depression around 1815-1822, followed by better growth, particularly visible in Ginals, where growth reached its highest values. Another growth depression is visible in the forest and lower treeline stands around 1915, mainly in Ginals. After a period with varying patterns, growth increased since the 1980s in all stands except in the forest of Ginals. Annual rings were found to be the widest at the end of the 1990s in these three stands. In both upper treeline stands there was a very visible decrease in growth in the late 1970s, with a return to a normal growth at the end of the measured period.

\section{DESCRIPTIVE STATISTICS OF CHRONOLOGIES}

The best part of the residual chronology, with a sufficient number of cores, was the longest in the forest stands (only the 20th century was retained here). In the treeline ecotone stands, the high proportion of young trees allowed only rather short chronologies (Table 1). The variance of residual chronologies accounted for by the first component (common variance among trees included in the chronology; Fritts, 1976) ranged between 31 and 45\%. The mean sensitivity was lower than 0.2 for all the stands, but increased in the upper treeline. The expressed population signal exceeded 0.85 in four stands and was closed in the forest stand of Grächen (Table 1). This value is considered as a threshold for reliable chronology (Wigley et al., 1984), but it was much too low in the upper treeline stand of Ginals.

The yearly correlations of the standardized chronologies between the stands were mostly highly significant (Table 2). Correlations between the Grächen stands were clearly better than

TABLE 2

Annual correlations of residual chronologies in the Grächen and Ginals sites for their common periods. Pearson correlation coefficients: *** highly significant $(p<0.001)$; * significant $(p<0.05)$; n.s. not significant.

\begin{tabular}{|c|c|c|c|c|c|c|c|}
\hline & \multirow[b]{2}{*}{ Stands } & \multicolumn{3}{|c|}{ Grächen } & \multicolumn{3}{|c|}{ Ginals } \\
\hline & & Forest & Lower treeline & Upper treeline & Forest & Lower treeline & Upper treeline \\
\hline \multirow[t]{3}{*}{ Grächen } & Forest & & & & & & \\
\hline & Lower treeline & $0.640 * * *$ & & & & & \\
\hline & Upper treeline & $0.504 * * *$ & $0.702 * * *$ & & & & \\
\hline \multirow[t]{3}{*}{ Ginals } & Forest & $0.619 * * *$ & $0.605^{* * *}$ & $0.484 * * *$ & & & \\
\hline & Lower treeline & $0.519^{* * *}$ & $0.557^{* * *}$ & $0.482 * * *$ & $0.492 * * *$ & & \\
\hline & Upper treeline & $0.298^{*}$ & $0.337^{*}$ & $0.584 * * *$ & $0.303^{*}$ & $0.314^{*}$ & \\
\hline
\end{tabular}


those between the Ginals stands. In both transects, correlations between closer stands were better than between distant ones. Between transects, the highest correlations generally occurred between stands at the same levels.

\section{CLIMATE INFLUENCE ON RADIAL GROWTH}

In the 20th century, temperature and growth were related in two different seasons. The first one was the positive correlation between growth and summer temperatures (Table 3). This was particularly visible in July, but several signals appear in May, June, and August in some stands. Autumn temperatures of the previous year were positively correlated with radial growth as well. Correlations were apparent mainly in November in forest stands, and to a lesser extent, in October or September in treeline stands (Table 3).

The main correlation between precipitation and growth was in the autumn of the previous year. High rainfall, especially in October, was positively related to growth in four stands (Table 3). The stronger correlation observed in lower stands extended toward the end of the year in some stands. Another positive correlation was recorded in August of the growing season in the two lower stands in Grächen.

\section{Discussion}

\section{TREELINE ECOTONE DENSIFICATION AND EXPANSION}

Since 1840, the treeline ecotone increased in density and expanded upslope in Grächen. The strong recruitment in forest and lower treeline stands happened in the middle of already existing trees (Fig. 3). However, there was a real upslope shift of the tree limit, as all the trees in the upper treeline stand were younger than 1840 (except one at $2540 \mathrm{~m}, 40 \mathrm{~m}$ lower than the current limit). Simultaneous forest expansion has already been observed in California (Taylor, 1995), the North American mountains (Brink, 1959; LaMarche, 1973; Bekker, 2005), the American boreal forest (Payette and Filion, 1985), Sweden (Kullman, 1986), and in the Ural Mountains (Shiyatov, 2003). At the same time, herbaceous alpine plants also expanded upslope (Braun-Blanquet, 1957). This expansion is generally associated with higher temperatures after the end of the Little Ice Age around 1850 (Esper et al., 2002).

However, tree recruitment in treeline ecotones does not depend only on higher temperature, and other factors may inhibit forest expansion. For example, Daniels and Veblen (2004) observed in the Andes that low moisture availability could limit tree recruitment. In the Spanish Pyrenees, Camarero and Gutiérrez (2004) observed an upslope expansion of the tree limit between 1850 and 1900, but no change later. They attributed this stability to the high interannual variability of March temperatures, which prevents seedling survival. Treeline expansion is sometimes limited by the weak seed dispersal and the better microclimatic conditions among existing trees, which promotes densification of the stands (Mazepa, 2005).

Little is known about necessary conditions for seedling establishment and survival of Pinus cembra. The nutcracker (Nucifraga caryocatactes L.) disperses the seeds and hides them in humus as winter caches, frequently above the treeline (Contini and Lavarelo, 1982). This species thus has a high potential for responding quickly to climate warming (Brubaker, 1986). Ridges, slopes, and rock ledges are preferred by the nutcracker to depressions as hiding places because of the smaller accumulation of snow (Tranquillini, 1979; Contini and Lavarelo, 1982). This is favorable to seedling survival as well, as long snow cover increases the risk of fungal parasitism in spring by Gremmeniella abietina (Lagerb.) Morelet or Phacidium infestans L. (e.g., Contini and Lavarelo, 1982; Schönenberger et al., 1990; Senn, 1999). Seedlings and saplings outside of snow cover (e.g., on wind-exposed ridges) are particularly sensitive to winter desiccation, when long-lasting soil freezing conditions are coupled with intense radiative warming (Tranquillini, 1979; Oberhuber, 2004). From these observations, we can conclude that survival of $P$. cembra seedlings is likely favored by a warm spring for a quick melting of snow and early snow falls at the beginning of winter to limit deep freezing of the soil. Long snow cover in spring is probably the most limiting factor, and the temperature increase during the growth season seems to have been the necessary and sufficient change to trigger the upslope expansion of the treeline after the Little Ice Age. Relatively humid summers could be important as well, as is the case for Pinus uncinata in the dry Spanish Pyrenees, but experiments showed that $P$. cembra seedlings are very tolerant of droughts (Hättenschwiler and Körner, 1995).

\section{TREELINE EXPANSION IN THE ALPS}

In the Alps, treeline expansion has already been observed but, up to now, it was difficult to interpret because the end of the Little Ice Age was almost simultaneous with the decrease in mountain agriculture (Motta and Nola, 2001). However, the delay of establishment in Ginals stands, an anthropogenic treeline, about 60 years after the establishment in Grächen stands, a natural treeline, showed that both events were not perfectly synchronous in this region (Fig. 3). The continuous decrease in agriculture in Swiss mountain regions started in the second half of the 19th century (Bätzing, 1991), but was sensitive in tree recruitment only at the beginning of the 20th century (Fig. 3). These periods of expansion are consistent with previous results. For example, Payette and Filion (1985) and Taylor (1995) found an expansion since about 1850 in natural conditions, while Stützer (1999) and Motta and Nola (2001) observed it mainly since 1920 in pastured areas. Under such conditions, it is likely that the already warmer climate facilitated the recolonization of subalpine grasslands, as the young seedlings have to withstand harsher microclimate conditions in the open areas than in the middle of trees at similar altitudes in Grächen stands (Holtmeier and Broll, 2005). Nowadays, the altitude difference of the treeline ecotones in both transects shows that the Ginals treeline is not yet in balance with climate and will certainly carry on its expansion.

\section{TREE GROWTH AND CLIMATE}

Cold temperatures are certainly the main limiting factor for tree growth in these treeline ecotones. All three growth depressions observed in radial growth were linked to cold periods (Fig. 2). The first one, around 1815-1822, was already recorded by Büntgen et al. (2005). It followed the Tambora eruption in Indonesia, which cooled the whole Northern Hemisphere (Briffa et al., 1998) during the already cold Dalton Minimum period (Esper et al., 2004). The year 1816 was characterized in the Swiss Alps by very bad weather and harvests (Seppey, 1986). LaMarche and Fritts (1971) found that the second growth depression visible around 1915 was correlated with the advance of many glaciers. Finally, the last one, observed in both upper treeline stands in the late 1970s, was simultaneous to lower summer temperatures (Fig. 2; Beniston et al., 1997). Recently established trees growing in conditions slightly above their physiological threshold have probably been stressed by 
TABLE 3

Results of the response function analyses of tree radial growth in relation to climate data in six stands (Central Swiss Alps). Analyses were performed on the the full chronology span period (Table 1). Significant coefficients are indicated with symbols.

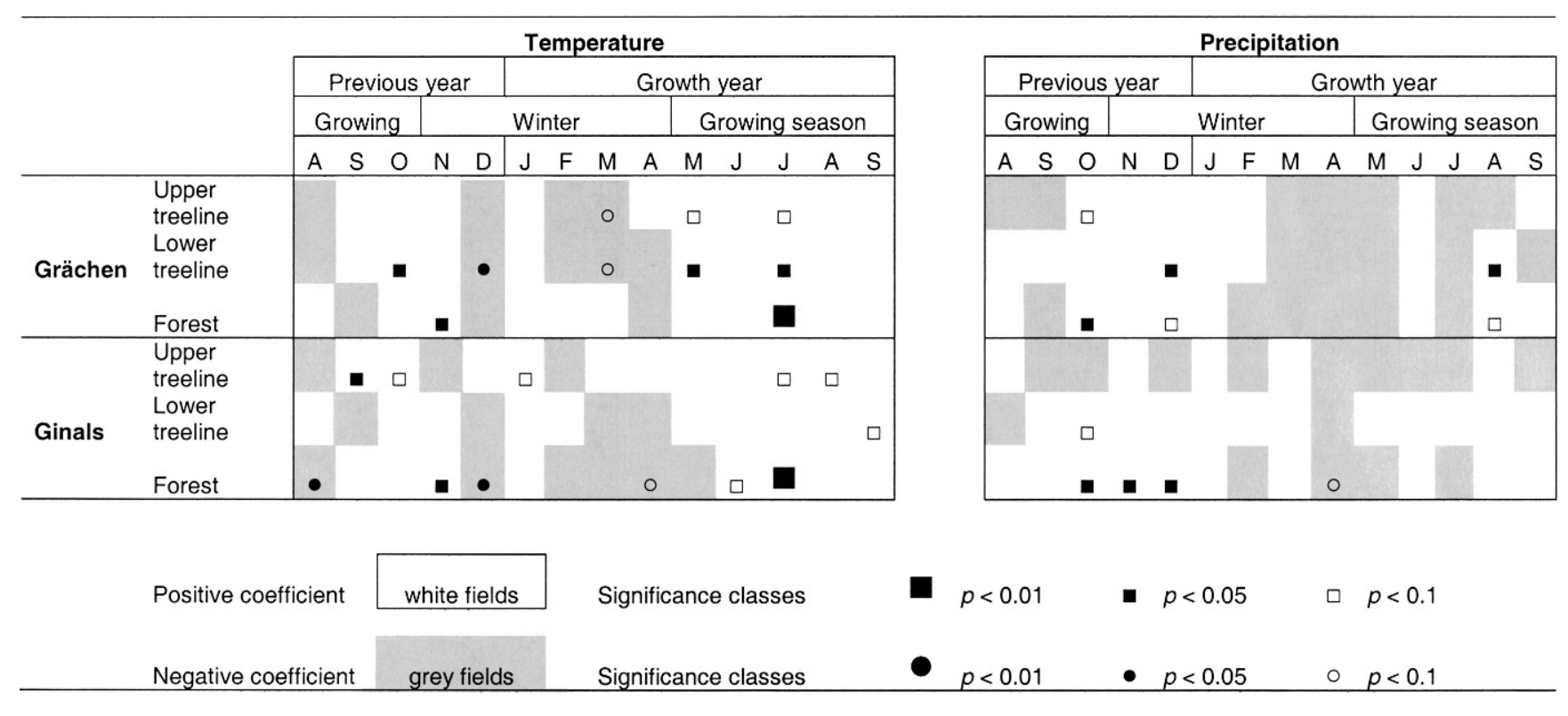

a succession of colder summers, while trees in lower stands have not been influenced (Kullman, 2001). Conversely, the radial growth increase observed in three stands (both lower treelines and forest in Grächen) coincided with a strong temperature increase (Fig. 2; Paulsen et al., 2000; Luterbacher et al., 2004; Rebetez and Dobbertin, 2004) and corresponds to a similar change observed in Larix decidua chronologies in the Swiss and French Alps (Petitcolas, 1998; Büntgen et al., 2005). Longer observations will be necessary to confirm this growth increase and to see if the upper treeline stands follow this trend.

The importance of high temperatures for growth was confirmed by the response function analyses. At both sites, and at almost all altitudes, the correlation between July temperatures and tree-ring growth was positive (Table 3), as has often been reported for trees at subalpine altitudes (e.g., P. cembra: Eckstein and Aniol, 1981; Petitcolas, 1998; and Picea abies: Lingg, 1986; Petitcolas, 1998). Warm temperatures during the previous autumn were favorable as well (Table 3). This period is after the end of treering growth and corresponds to the accumulation of reserves for the next season (Tranquillini, 1979; Contini and Lavarelo, 1982). This period is also at the end of needle cuticle development (Tranquillini, 1979; Oberhuber, 2004), which is an important stage for building up good protection against winter frost, drought, or wind.

However, in this dry part of the Alps, precipitation was positively correlated with growth as well (Table 3 ). The positive correlation with precipitation during the previous NovemberDecember period is probably related to snow cover. In these months, precipitation is mainly snow. An abundant, early snow cover provides good protection against soil frost and may help trees to avoid frost desiccation at the end of winter, when transpiration increases with temperature (Oberhuber, 2004). A light drought effect was visible during the growing season as well, with a positive correlation with rainfall in two stands in August and in four stands in the previous October (Table 3). Petitcolas (1998) observed similarly that low rainfall during the previous August affected growth of conifers in the inner French Alps. Tree rings are still growing in August in subalpine areas, and photosynthesis is possible for P. cembra until the end of October (Tranquillini, 1979). Körner (1995) suggested that trees are not directly sensitive to drought, but a lack of water stops microbiological activity in the soil, which decreases the availability of nutrients. However, in the dry inner Alps, it is possible that atmospheric humidity is low enough to reduce photosynthesis, which is greatly inhibited when air humidity falls below $50 \%$ (Tranquillini, 1979). The mean monthly air humidity values in Grächen are regularly around 60\% (minimum $48 \%$ in August 1989; MeteoSwiss), and daytime values are even lower.

\section{FUTURE TRENDS}

Since 1980, radial growth increased in five of the six considered $P$. cembra stands following the increase of summer temperatures. Annual ring growth at upper treeline is now as fast as in the forest stands (Fig. 2; Paulsen et al., 2000). As seedling recruitment and radial growth seem to respond similarly to warmer conditions, like those observed at the end of the Little Ice Age (Figs. 2 and 3), it is probable that colonization is ongoing at both sites, although we did not count and cut saplings to prove it. Phenological observations have shown that, in Switzerland, $P$. cembra is the best adapted conifer to colonize the lower alpine belt thanks to the decrease of the necessary degree-days for development with increasing elevation (Theurillat and Schlüssel, 2000).

Future colonization depends on tree establishment. Saplings have to cope with natural hazards for up to 50 years to ensure a successful recruitment (Szeicz and MacDonald, 1995) and hence are sensitive to a high climatic variability and extreme events like long snow cover in spring (Schönenberger et al., 1990; Taylor, 1995; Millar et al., 2004). Exceptional conditions have become more frequent since 1980 and are expected to increase significantly with global warming (Beniston et al., 1997; Rebetez et al., 1997; Schär et al., 2004). Thus, predictions on future recruitment in the 
treeline ecotone are difficult and need supplementary experiments and observations on sapling survival under exceptional conditions.

Even a drought-tolerant subalpine species, such as $P$. cembra, could increasingly suffer a moisture deficit. Drought stress is already visible in response function analyses (Table 3), and climate change models for the end of the 21 st century (Mitchell et al., 2004) are predicting drier summers (19-36\% decrease for June-August months) and warmer temperatures (annual mean increase of 3.4 $6.5^{\circ} \mathrm{C}$, increase for August of $5.9-11.3^{\circ} \mathrm{C}$ ). It is highly probable that radial growth will be limited, or even reduced, by these dry summer conditions, because of lower rainfall and higher evapotranspiration (Barber et al., 2000; Daniels and Veblen, 2004; Rebetez and Dobbertin, 2004; Holtmeier and Broll, 2005). Data on the consequences of the 2003 drought (Schär et al., 2004) would be very instructive on the behavior of $P$. cembra in very dry conditions.

\section{CONCLUSION}

Climate change and land-use have influenced treeline dynamics in the Alps. At the end of the Little Ice Age, Pinus cembra establishment and radial growth in the treeline ecotone were simultaneously favored by warmer climate. This ecotone quickly shifted upslope in a natural treeline, while a 60-year delay was observed in an anthropogenic treeline, and only after a decrease of cattle activity. Radial growth is strongly linked to summer temperature along the whole altitudinal gradient we considered, but our results suggest that growth could be limited by long periods of drought in the lowest stands.

The treeline ecotone expansion will certainly continue, at least in the previously pastured areas where present ecotone elevation is lower than in undisturbed situations. Further studies will be necessary to precisely identify the consequences of continued climate warming. Tree establishment depends on a series of consecutive favorable years while predicted decreasing summer precipitation may reduce tree growth. Future studies should include investigations of the influence of extreme events, like the 2003 summer drought.

\section{Acknowledgments}

This work has been supported by Lausanne University and the Swiss Federal Research Institute WSL (Antenne romande, Lausanne). We are grateful to Martine Rebetez for her helpful comments about regional climate; to Fawziah Gadallah, Edward Mitchell, and two anonymous reviewers for their positive and constructive feedback on a first draft of the manuscript; and to S. Dingwall for translation supervision.

\section{References Cited}

Barber, V. A., Juday, G. P., and Finney, B. P., 2000: Reduced growth of Alaskan white spruce in the twentieth century from temperature-induced drought stress. Nature, 405: 668-673.

Bätzing, W., 1991: Die Alpen. Entstehung und Gefährdung einer europäisch Kulturlandschaft. München: Beck Verlag, 287 pp.

Bekker, M. F., 2005: Positive feedback between tree establishment and patterns of subalpine forest advancement, Glacier National Park, Montana, U.S.A. Arctic, Antarctic, and Alpine Research, 37: 97-107.

Beniston, M., Diaz, H. F., and Bradley, R. S., 1997: Climatic change at high elevation sites: an overview. Climatic Change, 36: 233-251.

Braun-Blanquet, J., 1957: Ein Jahrhunder Florenwandel am Piz Linard $(3414 \mathrm{~m})$. Bulletin du Jardin Botanique de Bruxelles: 221-232.
Briffa, K. R., and Cook, E. R., 1990: Methods of response function analysis. In Cook, E. R., and Kairiukstis, L. A. (eds.), Methods of Dendrochronology. Dordrecht: Kluwer, 240-246.

Briffa, K. R., Jones, P. D., Schweingruber, F. H., Shiyatov, S. G., and Cook, E. R., 1995: Unusual twentieth-century summer warmth in a 1000-yr temperature record from Siberia. Nature, 376: $156-159$.

Briffa, K. R., Jones, P. D., Schweingruber, F. H., and Osborn, T. J., 1998: Influence of volcanic eruptions on Northern Hemisphere summer temperature over the past 600 years. Nature, 393: 450-455.

Brink, V. C., 1959: A directional change in the subalpine forestheath ecotone in Garibaldi Park, British Columbia. Ecology, 40: $10-16$.

Brockmann-Jerosch, H., 1919: Baumgrenze und Klimacharakter. Zürich: Rascher et Cie, 255 pp.

Brubaker, L. B., 1986: Responses of tree populations to climate change. Vegetatio, 67: 119-130.

Büntgen, U., Esper, J., Frank, D. C., Nicolussi, K., and Schmidhalter, M., 2005: A 1052-year tree-ring proxy for Alpine summer temperatures. Climate Dynamics, 25: 141-153.

Camarero, J. J., and Gutiérrez, E., 1999: Structure and recent recruitment at alpine forest-pasture ecotones in Spanish central Pyrenees. Ecoscience, 6: 451-464.

Camarero, J. J., and Gutiérrez, E., 2004: Pace and pattern of recent treeline dynamics: response of ecotones to climatic variability in the Spanish Pyrenees. Climatic Change, 63: $181-200$.

Contini, L., and Lavarelo, Y., 1982: Le pin cembro (Pinus cembra L.). Répartition, écologie, sylviculture et production. Paris: INRA, $197 \mathrm{pp}$.

Cook, E. R., 1985: A Time-Series Approach to Tree-Ring Standardization. Ph.D. thesis. University of Arizona, Tucson.

Daniels, L. D., and Veblen, T. T., 2004: Spatiotemporal influences of climate on altitudinal treeline in northern Patagonia. Ecology, 85: 1284-1296.

Duncan, R. P., 1989: An evaluation of errors in tree age estimates based on increment cores in Kahikatea (Dacrycarpus dacrydioides). New Zealand Natural Sciences, 16: 31-37.

Eckstein, D., and Aniol, R. W., 1981: Dendroclimatological reconstruction of the summer temperatures for an alpine region. Dickerwachstum der Bäumen, Mitteilungen der forstslichen Bundesversuchantsalt, Wien, 142: 391-398.

Esper, J., Cook, E. R., and Schweingruber, F. H., 2002: Lowfrequency signals in long tree-ring chronologies for reconstructing past temperature variability. Science, 295: 2250-2253.

Esper, J., Treydte, K., Frank, D. C., Gärtner, H., and Büntgen, U., 2004: Temperaturvariationen und Jahrringe. Schweizerische Zeitschrift für Forstwesen, 155: 213-221.

Fowler, A. M., 1998: XMATCH98: an interactive tree-ring crossdating program. Auckland: Auckland University Occasional Paper 38.

Fritts, H. C., 1976: Tree Rings and Climate. London: Academic Press, 567 pp.

Fritts, H. C., 1999: PRECON, version 5.17b (available from http:// www.ltrr.arizona.edu/webhome/hal/dlprecon.html).

Grissino-Mayer, H. D., Holmes, L., and Fritts, H. C., 1997: International Tree-Ring Data Bank Program Library, version 2.1. Tucson: University of Arizona, Laboratory of Tree-Ring Research.

Hättenschwiler, S., and Körner, C., 1995: Responses to recent climate warming of Pinus sylvestris and Pinus cembra within their montane transition zone in the Swiss Alps. Journal of Vegetation Science, 6: 357-368.

Holmes, R. L., 1983: Computer-assisted quality control in treering dating and measurement. Tree-Ring Bulletin, 43: 69-78.

Holtmeier, F. K., and Broll, G., 2005: Sensitivity and response of northern hemisphere altitudinal and polar treelines to environmental change at landscape and local scales. Global Ecology and Biogeography, 14: 395-410. 
Körner, C., 1995: Impact of atmospheric changes on alpine vegetation: the ecophysiological perspective. In Guisan, A., Holten, J. I., Spichiger, R., and Tessier, L. (eds.), Potential Ecological Impacts of Climate Change in the Alps and Fennoscandian Mountains. Chambésy: Conservatoire et Jardin Botaniques de la ville de Genève, 113-120.

Körner, C., and Paulsen, J., 2004: A world-wide study of high altitude treeline temperatures. Journal of Biogeography, 31: 713-732.

Kullman, L., 1986: Late Holocene reproductional patterns of Pinus sylvestris and Picea abies at the forest limit in central Sweden. Canadian Journal of Botany, 64: 1682-1690.

Kullman, L., 2001: Immigration of Picea abies into the northcentral Sweden. New evidence of regional expansion and treelimit evolution. Nordic Journal of Botany, 21: 39-54.

LaMarche, V. C., 1973: Holocene climatic variations inferred from treeline fluctuations in the White Mountains, California. Quaternary Research, 3: 632-660.

LaMarche, V. C., and Fritts, H. C., 1971: Tree rings, glacial advance, and climate in the Alps. Zeitschrift für Gletscherkunde und Glazialgeologie, 7: 125-131.

Lingg, W., 1986: Dendroökologische Studien an Nadelbäumen im alpinen Trockental Wallis (Schweiz). Berichte 287, Eidgenössische Anstalt für das forstliche Versuchswesen, Birmensdorf, $81 \mathrm{pp}$.

Lloyd, A. H., and Graumlich, L. J., 1997: Holocene dynamics of treeline forests in Sierra Nevada. Ecology, 78: 1199-1210.

Lloyd, W., and Fastie, C., 2002: Spatial and temporal variability in the growth and climate response of treeline trees in Alaska. Climatic Change, 52: 481-509.

Luterbacher, J., Dietrich, D., Xoplaki, E., Grosjean, M., and Wanner, H., 2004: European seasonal and annual temperature variability, trends and extremes since 1500. Science, 303: 1499-1503.

Mazepa, V. S., 2005: Stand density in the last millennium at the upper tree-line ecotone in the polar Ural Mountains. Canadian Journal of Forest Research, 35: 2082-2091.

Millar, C. I., Westfall, R. D., Delany, D. L., King, J. C., and Graumlich, L. J., 2004: Response of subalpine conifers in the Sierra Nevada, California, U.S.A., to 20th-century warming and decadal climate variability. Artic, Antarctic, and Alpine Research, 36: 181-200.

Mitchell, T. D., Carter, T. R., Jones, P. D., Hulme, M., and New, M., 2004: A Comprehensive Set of High-Resolution Grids of Monthly Climate for Europe and the Globe: the Observed Record (1901-2000) and 16 Scenarios (2001-2100). Norwich, United Kingdom: Tyndall Centre for Climate Change Research, Working Paper 55.

Motta, R., and Nola, P., 2001: Growth trends and dynamics in sub-alpine forest stands in the Varaita Valley (Piedmont, Italy) and their relationships with human activities and global change. Journal of Vegetation Science, 12: 219-230.

Noble, I. R., 1993: A model of the responses of ecotones to climate change. Ecological Applications, 3: 396-403.

Oberhuber, W., 2004: Influence of climate on radial growth of Pinus cembra within the alpine timberline ecotone. Tree Physiology, 24: 291-301.

Paulsen, J., Weber, U. M., and Körner, C., 2000: Tree growth near timberline: abrupt or gradual reduction with altitude? Artic, Antarctic, and Alpine Research, 32: 14-20.

Payette, S., and Filion, L., 1985: White spruce expansion at the tree line and recent climatic change. Canadian Journal of Forest Research, 15: 241-251.
Petitcolas, V., 1998: Dendroécologie comparée de l'épicéa, du mélèze, du pin cembro et du pin à crochets en limite supérieure de la forêt dans les Alpes françaises: influence de la variabilité macro-écologique. Thèse. Université Joseph Fourier, Grenoble, $188 \mathrm{pp}$.

Rebetez, M., and Dobbertin, M., 2004: Climate change may already threaten Scots pine stands in the Swiss Alps. Theoretical and Applied Climatology, 79: 1-9.

Rebetez, M., Lugon, R., and Baeriswyl, P.-A., 1997: Climatic change and debris flows in high mountain regions: the case study of the Ritigraben torrent (Swiss Alps). Climatic Change, 36: 371-389.

Rolland, C., Petitcolas, V., and Michalet, R., 1998: Changes in radial tree growth for Picea abies, Larix decidua, Pinus cembra and Pinus uncinata near the alpine timberline since 1750. Trees, 13: $40-53$

Schär, C., Vidale, P. L., Lüthi, D., Frei, C., Häberli, C., Liniger, M. A., and Appenzeller, C., 2004: The role of increasing temperature variability in European summer heatwaves. Nature, 427: $332-336$.

Schönenberger, W., Frey, W., and Leuenberger, F., 1990: Ökologie und Technik dere Aufforstung im Gebirge-Anregungen für die Praxis. Eidgenössische Anstalt für das forstliche Versuchswesen, 325: 1-58.

Schweingruber, F. H., 1985: Dendro-ecological zones in the coniferous forests of Europe. Dendrochronologia, 3: 67-75.

Senn, J., 1999: Tree mortality caused by Gremmeniella abietina in a subalpine afforestation in the central Alps and its relationship with duration of snow cover. European Journal of Forest Pathology, 29: 65-74.

Seppey, A.-M., 1986: Récits d'un meunier. Genève: Musée d'ethnographie, Monographic, Sierre, 239 pp.

Shiyatov, S. G., 2003: Rates of change in the upper treeline ecotone in the polar Ural Mountains. PAGES News, 11: 8-10.

Stützer, A., 1999: Im permanenten Überlebenskampf: Bäume über der Waldgrenze. Carinthia II, 109: 353-360.

Szeicz, J. M., and MacDonald, G. M., 1995: Recent white spruce dynamics at the subarctic alpine treeline of north-western Canada. Journal of Ecology, 83: 873-885.

Taylor, A. H., 1995: Forest expansion and climate change in the mountain hemlock (Tsuga mertensiana) zone, Lassen Volcanic National Park, California, U.S.A. Arctic and Alpine Research, 27: 207-216.

Theurillat, J.-P., and Schlüssel, A., 2000: Phenology and distribution strategy of key plant species within the subalpinealpine ecocline in the Valaisan Alps (Switzerland). Phytocoenologia, 30: 439-456.

Tinner, W., and Theurillat, J.-P., 2003: Uppermost limit, extent, and fluctuations of the timberline and treeline ecocline in the Swiss Central Alps during the past 11,500 years. Arctic, Antarctic, and Alpine Research, 35: 158-169.

Tranquillini, W., 1979: Physiological Ecology of the Alpine Timberline. Berlin: Springer Verlag, 137 pp.

Walter, H., and Lieth, H., 1967: Klimadiagramm-Weltatlas. Jena: VEB Gustav Fischer Verlag.

Wigley, T. M. L., Briffa, K. R., and Jones, P. D., 1984: On the average value of correlated time series, with applications in dendroclimatology and hydrometeorology. Journal of Climate and Applied Meteorology, 23: 201-221.

Ms accepted February 2007 